\title{
THE EFFECT OF PRIVATE SECURITY POLICE COOPERATION ON THE RELATIONSHIP BETWEEN JOB SATISFACTION AND OCCUPATIONAL COMMITMENT
}

Uğur DEMİRCi ${ }^{1}$

\section{ABSTRACT}

The purpose of this study is to test whether there is a mediating effect of private security officers' police cooperation perception on the relationship between job satisfaction and occupational commitment. The population of the study includes the private security officers working in Bursa. Random sampling is conducted in the study. As a result of the questionnaire, 702 data were found analyzable. In this study, the Job Satisfaction Scale developed by Weiss et al. (1967), the Occupational Commitment Scale developed by Meyer et al. (1993) and Private Security Police Cooperation Level Scale developed by the researcher were used. According to the result of the study, it was revealed that there is a positive relationship between job satisfaction and occupational commitment, and police cooperation perception partially mediates this relationship.

Keywords: Private Security, Police, Private Security Police Cooperation, Job Satisfaction, Occupational Commitment

JEL Codes: L29, M10, M12, M19

\section{IŞ DOYUMU ILLE MESLEKI BAĞLILIK İLIŞKISINE ÖZEL GÜVENLIK POLİS IŞ̧BIRLIĞIiNIN ETKİSi}

$\ddot{O} Z$

Bu araştırmanın temel amacı özel güvenlik görevlilerinin polis işbirliği algılarının is doyumu ile mesleki bă̆lılık arasındaki ilişkide aracılık etkisinin olup olmadığını test etmektir. Araştırmanın evrenini Bursa'da çalışan özel güvenlik görevlileri oluşturmaktadır. Araştırmada tesadüfi örneklem kullanılmıştır. Uygulanan anket neticesinde 702 veri analize uygun şekilde elde edilmiştir. Araştırmada Weiss vd. (1967) tarafindan gelişstirilen Iş̧ Doyumu Ölçeği, Meyer vd. (1993) tarafindan geliştirilen Mesleki Bağlllık Ölçeği ve araştırmacı tarafindan geliştirilen Özel Güvenlik Polis İşbirliği Düzeyi Ölçeği kullanılmıştır. Araştırma sonuçlarına göre iş doyumu ile mesleki bağlılık arasında pozitif yönlü ilişki olduğu, polis işbirliğ $\check{i}$ algısının bu ilişkiye kısmi aracılık ettiği tespit edilmiştir.

Anahtar Kelimeler: Özel Güvenlik, Polis, Özel Güvenlik Polis İşbirliği, İş Doyumu, Mesleki Bă̆lılık

JEL Kodlart: L29, M10, M12, M19

\footnotetext{
${ }^{1}$ Dr. Emniyet Genel Müdürlüğü ugurdemirci@ yahoo.com
} 


\section{INTRODUCTION}

Parallel to the developments in the world, the private security industry in Turkey is growing day by day. The number of private security personnel employed in the industry is also increasing along with the increasing number of private security companies and training institutions. However, when the number of private security ID card holders are taken into consideration, it is found out that nearly three times more of the personnel currently employed in the industry are not employed. Many factors such as heavy working conditions and low wages can cause private security officials to leave the private security profession and look for other alternatives. This situation leads to the loss of competent human resources in the industry and thus the loss of investments spent for that kind of human resource. One of the alternatives to change this situation can be to take measures which positively affect the attitudes of private security officers towards their profession.

Occupational commitment is related to how the individual keeps his profession at the center of his life (Baysal ve Paksoy, 1999). When the profession occupies an important place in the life of the individual, he/she starts to internalize the values and ideology of the profession (Morrow, 1983: 489). With high occupational commitment, the motivation and productivity of individual increases (Güleryüz et al., 2008; Jauch et al., 1978), and intention to quit reduces (Schmidt and Lee, 2008; Lu, et al., 2002). At the same time, it is understood from the results of the researches (Blau, 2000; Lee et al., 2000; Benligiray and Sönmez, 2011; Aslan, 2008) that the professionally committed employee will have many job attitudes that avail the organizations.

In the literature, there are many individual, organizational and professional factors affecting the occupational commitment of employees (Meyer and Espinoza, 2016). One of them among all the above-mentioned factors is job satisfaction. In the literature, there are many studies indicating that job satisfaction and occupational commitment are related (Lu, et al., 2002; Kaldenberg et al., 1995; Tak and Çiftçioğlu, 2008: Cetin, 2006). For this reason, it can be stated that taking measures to increase the job satisfaction of private security officers can be effective on their occupational commitment.

However, the relationship level between job satisfaction and occupational commitment vary in the literature. This refers that there may be some factors affecting the relationship between the two variables. Moreover, the presence of studies showing there are factors which 
partially mediates this relationship (Barac et al., 2018) indicates that there may as well be other mediating factors affecting this relationship.

Due to the nature of their work, private security and police are in very close relation. Moreover, they cooperate in many fields with the projects developed within the scope of publicprivate cooperation. The climate created by the positive results of this relationship and cooperation can have an impact on job satisfaction and occupational commitment of private security officers. Demirci (2019a, b) in his works have determined that the private security officers' police cooperation perception has an impact on job satisfaction and occupational commitment of private security officers. Therefore, it is considered that the private security officers' police cooperation perception, which has been found effective on both job satisfaction and occupational commitment, may have a mediating effect in the relationship between the variables. This research was carried out in order to find answers to the questions "Does private security officers police cooperation perception effect the relationship between job satisfaction and occupational commitment?", "Does private security officers police cooperation perception mediates the relationship between job satisfaction and occupational commitment?"

As a result of the analysis carried out in the light of the data obtained within the scope of the research, it was determined that the private security officers' police cooperation perception has a partial mediation effect on the relationship between job satisfaction and occupational commitment.

\section{CONCEPTUAL FRAMEWORK}

\subsection{Private Security Industry in Turkey}

The first legislation concerning the regulation of private security activities in Turkey came into force in 1981. However, the Law no 2495 "Maintaining the Protection and Establishing the Safety of Some Institutions" is not introduced to pave the way for the private sector in general, but rather for the purpose of ensuring the protection of the institutions which have high economic value for the state (Demirci, 2019a). Although the scope of the Law was tried to be expanded with the amendments made in 1992 and 1995, it was argued that it could not meet the demands for private security in parallel with the developments in the world (Gülcü, 2002:58). In 2004, Law no 5188 "Private Security Services" was adopted, and the obstacles against the development of the private sector were aimed to be eliminated. After this milestone, private security companies started to be established and started to serve the private sector (Demirci, 2019a). 
As it is seen in Table 1 that the private security company, which was 15 in 2004, reached 1429 in 2018 and the training institutions, which were 12, reached 445. Similarly, the number of private security ID card holders increased from 57,855 in 2004 to 1,122,225 in 2018, while the number of employed private security officers increased from 21,376 in 2004 to 312,244 in 2018. As of October the 2018, of the 312,244 currently employed private security officers, 97,718 of them are employed in the public sector and 214,526 in the private sector. It is understood from the numbers that after the new law was enacted in 2004, the industry started to grow rapidly.

Table 1. The Number of Private Security Companies, Training Institutions, and Private Security Officers

\begin{tabular}{|l|l|l|l|l|l|l|l|l|}
\hline & $\mathbf{2 0 0 4}$ & $\mathbf{2 0 1 2}$ & $\mathbf{2 0 1 3}$ & $\mathbf{2 0 1 4}$ & $\mathbf{2 0 1 5}$ & $\mathbf{2 0 1 6}$ & $\mathbf{2 0 1 7}$ & $\begin{array}{l}\mathbf{2 0 1 8} \\
\text { October }\end{array}$ \\
\hline Private security companies & 15 & 1.013 & 1.111 & 1.330 & 1.389 & 1.406 & 1.441 & 1.429 \\
\hline Training institutions & 12 & 419 & 557 & 514 & 468 & 455 & 444 & 445 \\
\hline $\begin{array}{l}\text { Private security officers } \\
\text { who has ID card }\end{array}$ & 57.855 & 574.324 & 612.456 & 698.658 & 769.712 & 791.209 & 925.688 & 1.122 .225 \\
\hline $\begin{array}{l}\text { Private security officers } \\
\text { who are currently working }\end{array}$ & 21.376 & 172.717 & 212.561 & 239.356 & 252.378 & 263.621 & 292.300 & 312.244 \\
\hline
\end{tabular}

Table 2. The Public-Private Distribution of Private Security Officers

\begin{tabular}{|c|c|}
\hline Private security officers who work at public & Private security officers who work in private sector \\
\hline 97.718 & 214.526 \\
\hline \multicolumn{2}{|c|}{312.244} \\
\hline
\end{tabular}

Private security is a growing industry in the world. The study conducted by The Guardian $^{2}$ in 2017 indicates that the industry has a value of 180 billion dollars and will reach a value of 240 billion dollars in 2020. It is also stated in the same study that in more than 40 countries the number of private security officers is more than the number of police officers, and

\footnotetext{
${ }^{2}$ https://www.forbes.com/sites/niallmccarthy/2017/08/31/private-security-outnumbers-the-police-in-most-countries-worldwide-infographic/\# 4e4fed94210f Date of access: 10.10.2018
} 
more than 20 million private security officers are working in this industry. Meanwhile, it is known that the financial size of the private security industry in Turkey has exceeded 3 billion Euros $^{3}$. Hence, in accordance with the above-mentioned information, it would not be wrong to assume that the private security industry in Turkey has growth potential with a parallel in the world (Demirci, 2019a).

\subsection{Private Security Officers' Employment Forms in Turkey}

Private security officers used to be employed as a civil servant in the public sector as per the Law no 2495, but after 2004, they were started to be employed as a worker in the private sector pertaining to the Law no 5188. After this time the public sector has purchased this service from private security companies via subcontracting. Moreover, as a result of the amendment made with the Decree-Law No 696 in 2018, private security officers, who had been assigned in the public sector through subcontractors, were started to be employed in the public sector as public workers. However, Decree-Law No 696 lets municipalities only receive private security services through the private security personnel they employ in companies affiliated to municipalities (Demirci, 2019a).

Meanwhile, Law no 5188 stipulated that private security service could be provided in two different ways at the places. One of them is the way that the person, institution or organization employ private security personnel itself. In this method, which is called unit, the person, the institution or the organization undertakes the responsibilities under the Law no. 5188 including all personal rights of private security officers. The second method is subcontracting. The person, institution or organization who obtained private security permission can buy services from companies that have been established to provide this service and have obtained permission from the Ministry of Interior. In this case, private security companies are responsible for the personal rights and responsibilities under the Law no 5188 of the private security officers (Demirci, 2019a).

In this frame, private security officers are to be employed in four different areas. The figure on the employment forms of private security officers is presented below (Demirci, 2019a).

${ }^{3}$ It is declared in the European Private Security Companies Associations' 01.07.2017 dated annual report that the size of private security sector in Turkey is referred as 3.167 billion dollars. http://www.coess.org/newsroom.php?page=facts-and-figures, Date of access: 10.10 .2018 


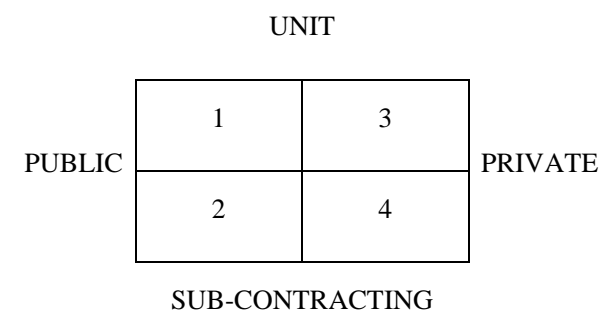

Figure 1. Private Security Officer's Employment Forms

The first area is the form of public self-employment (public/unit). The second area is the form of public subcontracting employment (public/sub-contracting). This is a privilege provided only to the municipalities with the Decree-Law no 696. Municipalities can get this service only through private security companies which they have been established within municipalities own bodies. The third area is the form of private self-employment (private/unit). The fourth area is the form of private subcontracting employment (private/sub-contracting).

\subsection{Occupational Commitment}

Occupational commitment is simply defined as a psychological link between an individual and his/her profession that was based on an effective reaction to that profession (Lee et al., 2000:800). Meyer et al. (1993) frame the occupational commitment to the psychological relationship between the individual and his profession, and the emotional response to his profession. Baysal and Paksoy (1999) also define occupational commitment as the degree to which the individual evaluates his profession in the center of his life. So, it can be stated that occupational commitment refers to prioritizing professional identity, struggle for the profession, and adhering to professional goals, norms, values, and ethical principles (Lanchman and Aranya, 1986). Thus, when the profession occupies an important place in the life of the individual, he/she starts to internalize the values and ideology of the profession (Morrow, 1983: 489). Since then, the profession becomes more than a job to earn money. Individuals who belong to the profession, in order to be successful, need a deeper commitment that goes beyond the desire to earn money (Benligiray and Sönmez, 2011: 29). Blau (2001) assumes occupational commitment as the most descriptive type of commitment.

Occupational commitment has been dealt with in a single and multidimensional way by various researchers (Blau, 2003; Meyer, et al., 1993; Aranya and Ferris; 1984). In this study, three sub-dimensions (Affective, continuance and normative) are mentioned because of the three-dimensional structure of Meyer, Allen and Smith (1993) is used. Affective commitment is that since the individual loves his profession he/she wants to stay in the profession. 
Continuance commitment refers to the cost related to leaving the organization. So, individual cannot leave the organization since he/she needs to (Goswami et al. (2007:14). Normative commitment is the perceived sense of obligation to stay in the profession with responsibility due to individuals' awareness that commitment is obligatory (Awalina, et al. 2015:22).

In the literature review, it is understood that there were many individual, organizational and professional antecedents of occupational commitment (Meyer and Espinoza, 2016). Age (Benligiray, and Sönmez, 2013; Meyer et al., 1993; Parasuraman and Nachman, 1987), gender (Cunningham et al., 2012; Lee et al., 2000; Snape, et al., 2008), ethic (Özer and Uyar, 2010), experience, occupational tenure, seniority (Benligiray, and Sönmez, 2013; Tang et al., 2012; Ozmen et al., 2005; Meyer et al., 1993), educational status (Benligiray, and Sonmez, 2013; Cohen, 2007), stress (Aydin, 2010), perceived occupational image (Lim, et al., 2000), organizational commitment (Cohen, 2007), motivation (Lauermann et al., 2017), job satisfaction ( $\mathrm{Lu}$, et al., 2002; Kaldenberg et al., 1995; Tak and Çiftçioğlu, 2008), pay satisfaction, work-itself satisfaction, supervision satisfaction, co-workers satisfaction, promotion opportunities satisfaction (Shamina, 2014) and burnout (Raiziene and Endriulaitiene, 2007) are some of the antecedents of occupational commitment. In addition, occupational commitment is positively related to productivity, motivation (Güleryüz et al., 2008; Jauch et al., 1978), job satisfaction, organizational commitment (Blau, 2000; Lee, et al., 2000), commitment to work, commitment to family (Benligiray and Sönmez, 2011), organizational citizenship behavior (Aledeinat et al., 2017; Aslan, 2008) and life satisfaction (Özdevecioğlu and Aktaş, 2007). It is also negatively related to intention to quit (Schmidt and Lee, 2008; Lu, et al., 2002), absenteeism (Woods et al. 2012: Louis, 1998) and burnout (Yetgin, 2017; Firat, 2015).

\subsection{Job Satisfaction}

Job satisfaction can be defined as a combination of psychological, physiological and environmental circumstances which cause an individual honestly to say I am satisfied with my job (Hoppock, 1935). Vieira (2005: 39) states that job satisfaction is an indicator of how happy an employee with his job. Ellickson and Logsdon (2002) defined job satisfaction as the extent to which employees like their job. Although positive attitudes towards the job indicate job satisfaction, negative and unfavorable attitudes towards the job indicate job dissatisfaction (Armstrong, 2006). It is understood in the literature that job satisfaction is effected by many factors such as age (Saner and Eyüpoğlu, 2012), gender (Ocpara et al., 2005), work condition, fairness, promotion, pay (Parvin and Kabir, 2011; Nguyen et al, 2002), education (Gürbüz, 
2007), job safety and security, working conditions, job autonomy, relationship with co-workers, relationship with supervisors, nature of work (Khan et al, 2011) leadership style (Mccann et al. 2014) stress (Ahsan et al., 2008) and feedback (Culbertson et al., 2013).

On the other hand, job satisfaction results in increased performance (Yazıcıoğlu, 2010; Crossman and Abou-Zaki, 2003; Nelson ve Quick 1995), increased productivity (Böckerman ve Ilmakunnas, 2012; Iaffaldano and Muchinsky 1985), high organizational commitment (Karataş ve Güleş, 2010), increased job involvement (Nwankwo et al., 2016), high organizational citizenship behavior (Foote et al., 2008), increased motivation (Y1lmaz, 2014; Furnham et al., 2009), high life satisfaction (Aydıntan ve Koç, 2016), and high mental health (Nadinloyi et al., 2013). In addition, if job satisfaction is not enhanced, many problems occur at the organizations such as high turnover (Jalagat vd., 2017: Locke, 1995), low occupational commitment (Lu et al., 2002), and high level of absenteeism (McShane, 1984). Moreover, Şimşek et al. (2007:11) stated that low job satisfaction causes high conflict, high stress, high theft rate, high strikes, and low mental and physical health at the workplace.

\subsection{Private Security-Police Relationship and Cooperation}

There are some reasons that private security and police are in relations in many areas. First of all, they mostly work together. Second, there has been an increasing awareness that the projects developed between the police and private security are vital to enhancing cities more secure. Third, since private security officers have the potential to use of force this capability is being considered a threat by the states. So, all private security-related issues are to be conducted by police (Demirci, 2019a).

As it is indicated in the first article of the Law no. 5188, private security is complementary to public security. Since public security is under the authority and responsibility of the law enforcement agencies including police, private security and police often get in contact while they are on duty. Also, it is known that they work together at some points. Malls, airports, and sports areas can be count as examples for these areas. Moreover, this kind of areas is tried to be expanded by the officials as it is in Antalya. Private security and police deployed together to enhance public security at Konyaaltı Beaches in Antalya ${ }^{4}$. Also, this relationship expended to the collaboration between police and private security in a number of areas

\footnotetext{
4 https://www.haberturk.com/antalya-haberleri/69049888-baskan-sili-sahillerde-ozel-guvenlik-uygulamasini-surduruyoruz Date of access: 14.05 .2019
} 
including responding to crimes, investigating crime, and sharing intelligence and knowledge (Wakefield, 2003: 200).

The importance of the cooperation between the police and the private security regarding maintaining public safety has become a crucial issue across the world. Hence, many Public Private Partnership (PPP) projects have been developed in many countries such as UK (CoESS, 2010), Netherlands (Van den Berg, 1995), US (Griffiths and Montgomery, 2015: 26-27), and Australia (Crime Research Center, 2008). As the Griffin Project is well-known of these project conducted in 2004, many more have been conducted in other countries. For example in the US, there are a variety of public police-private security partnership projects including networking, information sharing, crime prevention, resource sharing, training, operations, etc. (Griffiths and Montgomery, 2015: 27). Nalla and Hwang (2006: 487) stated that the trend in the last thirty years shows that police and private security cooperation will continue to increase. Also, Sarre (2011) stated that this cooperation is to be encouraged.

Meanwhile, since the private security officers have the possibility to use force, the states consider this capability as a threat. Hence, they want to control this force. All works related to the establishment of private security companies, identification of private security personnel, and giving private security permission for the person who wants to receive private security services are under the control of the states. On behalf of the states, as a public officer, the police is conducting all these private security-related issues including inspection of all private security elements. In this respect, police and private security officers often get in contact together.

There are researches in the literature on relations between police and private security. However, it is seen that few of the studies paid attention to the security relationship of police and private security officers (Chinwokwu, 2018; Sotlar and Mesko, 2009; Nalla and Hwang, 2006; Nalla and Hummer, 1999; Morley and Fong, 1995; Cunningham and Taylor, 1985). Chinwokwu (2018) found out in his study that private security companies and police see their relationship as cordial and complementary, although sometimes unequal and competitive. Moreover, he added in his study that interagency collaboration and networking need to be improved. Sotlar and Mesko (2009) stated in their study that both police and private security officers described their relations cooperative. Nalla and Hwang (2006) found in their study in South Korea that private security officers and policemen described the relationship between them as positive, and that they believe that the other party should be encouraged to develop a positive business relationship. Nalla and Hummer (1999) found that the perception of private security in relation to the police was positive in their study; however, they believe that private 
security officers did not believe that the police had positively relied on private security. In the same study, it was also found that private security respected the police but the police's point of view of private security was neutral. However, it is stated that the police has defined the relationship with private security as good and that private security defines this relationship as weak. Morley and Fong (1995), in his study of police private security relationships in California, found that private security was more optimistic in police relations than the police. Cunningham and Taylor (1985), in his study on police chiefs and private security directors, found that the police did not trust private security, but requested police information from them. Also, the results of the researches show that the perceptions of the police and the private security officers towards each other differ.

\subsection{The Relationship among Job Satisfaction, Occupational Commitment, and} Perception of Private Security Police Cooperation

In literature review it is seen that there are studies on relationship between job satisfaction and occupational commitment (Barac et al., 2018; Satoh et al., 2017; Kuo, 2014; Moradi et al., 2013; Wang et al., 2011; Lu et al., 2007: Cetin, 2006). However, the results of these studies differ. In one of these studies, Moradi et al. (2013) found a .324 (weak) correlation between job satisfaction and occupational commitment. In another study, Barac et al. (2018) found a .464 (moderate) correlation between job satisfaction and occupational commitment. Wang et al. (2011) found a .714 (high) correlation between job satisfaction and occupational commitment. The first hypothesis of the research with the conclusion of this literature review is the following:

\section{$\boldsymbol{H}_{1}:$ There is a relationship between job satisfaction and occupational commitment.}

The results revealed in the above-mentioned studies suggest that there may be factors affecting the relationship between job satisfaction and occupational commitment. As a matter of fact, Barac et al. (2018) found that core self-evaluation partially mediated the relationship between professional commitment and job satisfaction. The existence of the partial mediating effect indicates that another variable can mediate the relationship between the dependent and the independent variable (Baron and Kenny, 1986: 116). Therefore, the determination of other factors affecting the relationship between job satisfaction and occupational commitment is important to understand and explain the relationship between these two variables.

The private security officers' police cooperation perception is positively related to job satisfaction (Demirci, 2019a) and occupational commitment (Demirci, 2019b). In this context, 
the perception of private security police cooperation can also be effective in the relationship between job satisfaction and occupational commitment. There is no related research in the literature. Thus, the second hypothesis of the study is as follows:

$\boldsymbol{H}_{2}$ : The private security officers' police cooperation perception has an effect on the relationship between job satisfaction and occupational commitment.

\section{METHOD}

\subsection{Purpose and Model of the Study}

The purpose of this study is to test whether there is a mediating effect of the private security officers' police cooperation perception on the relationship between job satisfaction and occupational commitment. The design of the study, which was carried out within the framework of the quantitative paradigm, was determined as relational research. For this purpose, a questionnaire including the relevant scales was applied to private security officers working in Bursa to determine their job satisfaction, occupational commitment, and police cooperation perception. In addition, the following model was formed as a result of the literature review.

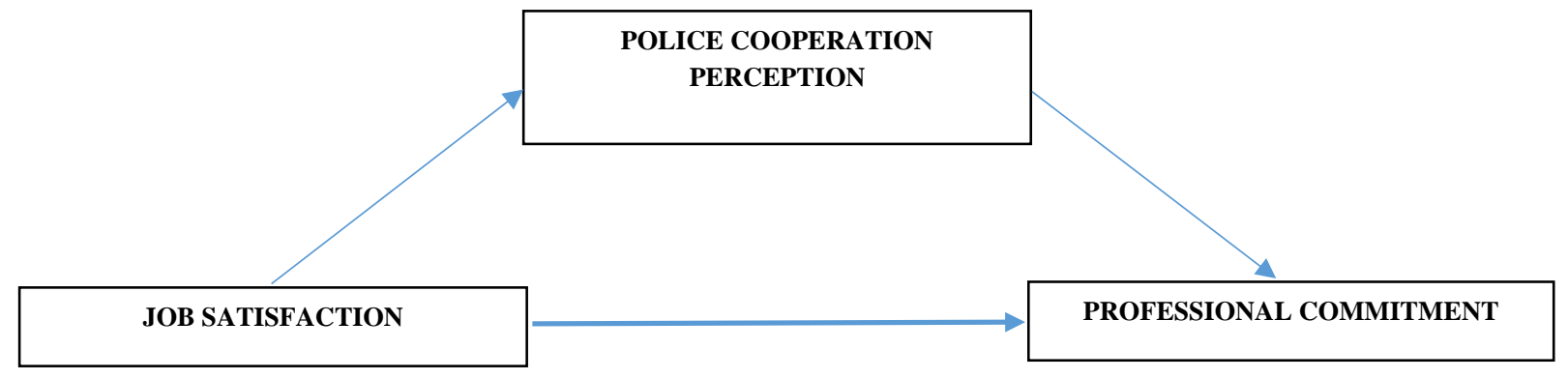

Figure 2. Model

In this study, the method proposed by Baron and Kenny (1986) was used to test the effect of mediation. Mediation relationship is tested with the model mentioned in Figure 3. In this model, the $\mathrm{X}$ represents the independent variable, $\mathrm{Y}$ represents the dependent variable and the $\mathrm{M}$ represents the mediator variable. In addition, c' pathway shows the effect between the independent and the dependent variable, the path a shows the effect between the independent variable and the mediator variable, and the path $b$ shows the effect between the mediator and the dependent variable (Baron and Kenny, 1986: 1176). 


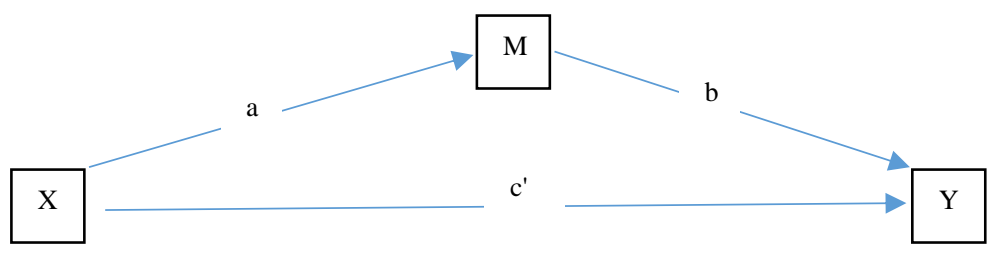

Figure 3. Mediator Effect Model

In case of a mediation, below-mentioned conditions must be met (Baron and Kenny, 1986:1176):

1. Independent variable must have an effect on the mediator.

2. Independent variable must have an effect on the dependent variable.

3. When the mediator is included in the regression analysis in the second step; if there is no meaningful relationship between the independent and the dependent variable, it can be mentioned that there is a full mediating effect. However, if there is a decrease in the relationship between the independent and the dependent variables, the partial mediating effect can be mentioned.

On the other hand, in order to be able to talk about the mediating effect, it should be also determined whether the indirect effect of the independent variable on the dependent variable (through the mediator) is significant. Therefore, the Sobel Test (Sobel, 1982; Sobel, 1986) was applied in the study.

\subsection{Universe and Sample of the Study}

The universe of this study consists of private security officers working in Bursa. As of November 2018, 14.951 private security officers work in Bursa. Of these, 3,940 are working at public, 11,011 are working in the private sector. Of the private security officer's work in the private sector, 5,238 are working at units and 5,773 are working for private security companies.

Table 3. Public-Private Distribution of Private Security Officers Who Work in Bursa

\begin{tabular}{|c|c|c|}
\hline \multirow{2}{*}{$\begin{array}{c}\text { Private security officers who work } \\
\text { at public }\end{array}$} & Private security officers who work in private sector \\
\hline \multirow{2}{*}{$\mathbf{3 . 9 4 0}$} & 5.238 & Belongs to companies \\
\hline & & \\
\hline
\end{tabular}


A random sample was used in the study. The survey, which was prepared and sent by online, was sent to all public and private security unit supervisors and private security company supervisors in Bursa on early November in 2018. It was aimed to reach all the universe neutral by asking the supervisors to send the questionnaire to all private security officers in Bursa. Also, participant responses were checked on a daily basis. The answers were discussed within the framework of the above mentioned and naturally occurring quotas (public-private / unitsubcontracting) and 10 days after the first announcement, the research announcement was repeated once again. Since the participation did not continue, the survey was closed to the answers at the end of November 2018. At the end of this period, 702 observation units were obtained.

\subsection{Data Collection Tool}

The questionnaire was used as a data collection tool. The questionnaire was prepared using the Minnesota Job Satisfaction Scale developed by Weiss et al. (1967), the Occupational Commitment Scale developed by Meyer et al. (1993) and the Private Security Police Cooperation Level Scale developed by the researcher (Demirci, 2019a).

\section{Minnesota Job Satisfaction Scale}

The Minnesota Job Satisfaction Scale was translated into Turkish by Oran (1989). The scale has two forms, one of it consists of 100, and the other consists of 20 questions. The reliability and validity of the scale have been tested in a large number of studies (Ghiselli et al., 2001; Hançer ve George, 2003; Sevimli et al., 2005). The scale consists of two sub-dimensions which determine the level of internal, external and general satisfaction. Internal satisfaction generally refers to internal situations such as success, appreciation, promotion, change of duty and responsibility. External satisfaction refers to non-individual situations such as working conditions, wage policies, relations with superiors and the form of supervision (Weiss et al. 1967: 4-5). In this study, the 20-item short form of the scale was used. The original reliability coefficient of the scale is .830. The Cronbach Alpha value of the scale used in this study was .961. Also, as a result of the normality test, it was determined that all skewness and kurtosis values were between $+1,5$ and $-1,5$. So, the data were evaluated as normally distributed (Tabachnick and Fidell, 2013).

\section{Occupational Commitment Scale}

The Occupational Commitment Scale developed by Meyer, Allen, and Smith (1993) was previously translated into Turkish and tested for validity and reliability (Yetgin, 2017; 
Özmen et al., 2005; Baysal and Paksoy, 1999). The scale includes three sub-dimension and 18 items with affective commitment, continuance commitment, and normative commitment. In this study, Cronbach Alpha value of the scale was obtained as .889. Also, as a result of the normality test, it was determined that all skewness and kurtosis values were between $+1,5$ and -1,5. Hence, the data were evaluated as normally distributed (Tabachnick and Fidell, 2013).

\section{Private Security Police Cooperation Level Scale}

It is understood from the literature review that the perception of private security police cooperation can be measured. However, due to the lack of a Turkish scale to measure the perception of private security police cooperation, scale development studies were initiated. For this purpose, interviews were carried out with private security officers to create an item pool. The interview was carried out with 5 private security officers who were working at public and 7 private security officers who were working in the private sector. 8 of the interviewee are male and 4 of them female. Also, two of them were a supervisor. During the interviews, the question "How do you understand the concept of private security-police cooperation?" was asked to private security officers. The answers are "to provide support when needed, to perform adequate communication, to have a mutual agreement, to speak the same language, to help when needed, to work towards the same purpose". When the responses of the private security officers, started to be repeated within the same concepts, the interviews were ended by considering that the answers were sufficient (Demirci, 2019a).

Question pool was created based on the interview results. The items formed were subjected to the supervision of two academicians within the scope of expert opinion. After the expert opinion, the draft scale formed consists of 6 items. Scale items are as follows (Demirci, 2019a):

1. I can provide adequate communication with the police during my duty.

2. In general, private security - police cooperation is at the top level.

3. We work for the same purpose as the police.

4. I feel enough support from the police whenever I need them.

5. Regarding my work, we can easily agree with the police.

6. The police always help me to overcome the difficulties I encounter during my work. 
The pilot application was conducted with 5-point Likert-shaped scale (1-Strongly disagree / 5-Strongly agree). Within the scope of the pilot application, data were obtained from 64 private security officers. Demographics of the participants are presented in the below table (Demirci, 2019a).

Table 4. Pilot Application Participants’ Demographics

\begin{tabular}{|c|c|c|c|}
\hline Variables & Variable groups & $\mathbf{n}$ & $\%$ \\
\hline \multirow{2}{*}{ Sex } & Male & 44 & 68,8 \\
\hline & Female & 20 & 31,3 \\
\hline \multirow{4}{*}{ Age } & Between 18-23 & 1 & 1,6 \\
\hline & Between 24-29 & 10 & 15,6 \\
\hline & Between 30-35 & 15 & 23,4 \\
\hline & 36 and more & 38 & 59,4 \\
\hline \multirow{2}{*}{ Marital status } & Married & 48 & 75 \\
\hline & Single & 16 & 25 \\
\hline \multirow{5}{*}{ Educational level } & Primary school & 3 & 4,7 \\
\hline & High school & 26 & 40,6 \\
\hline & Undergraduate & 5 & 7,8 \\
\hline & Graduate & 27 & 42,2 \\
\hline & Postgraduate & 3 & 4,7 \\
\hline \multirow{4}{*}{ Tenure } & Less than 1 year & 2 & 3,1 \\
\hline & Between 1-5 years & 17 & 26,6 \\
\hline & Between 6-10 years & 11 & 17,2 \\
\hline & 11 year and more & 34 & 53,1 \\
\hline \multirow{4}{*}{ Salary } & Between 1500-2000 TL. & 11 & 17,2 \\
\hline & Between 2001-2500 TL. & 24 & 37,5 \\
\hline & Between 2501-3000 TL. & 13 & 20,3 \\
\hline & 3001 TL. and more & 16 & 25 \\
\hline \multirow{2}{*}{ Employment } & Public & 40 & 62,5 \\
\hline & Private & 24 & 37,5 \\
\hline
\end{tabular}

In order to test the validity and reliability of the prepared scale, firstly Explanatory Factor Analysis (EFA) was performed with "varimax" and then Confirmatory Factor Analysis (CFA) was performed. According to the results of KMO sample adequacy statistics obtained within the scope of Explanatory Factor Analysis, interdepartmental links were highly 
compatible with factor analysis $(\mathrm{KMO}=0.900)$. Regarding the Bartlett Sphericity test results, a sufficient relation was found between the items (chi-square $(15)=355,608 ; p<0,001)$. The scale can explain $77,73 \%$ of the total variance in this one dimension form. Factor load values related to items of the prepared scale are presented in Table 5 (Demirci, 2019a).

Table 5. Draft Scales' Items Factor Loaded

\begin{tabular}{|l|c|}
\hline \multicolumn{1}{|c|}{ Items } & Factor loaded \\
\hline 1. I can provide adequate communication with the police during my duty. &, 930 \\
\hline 2. In general, private security - police cooperation is at the top level. &, 834 \\
\hline 3. We work for the same purpose as the police. &,- 758 \\
\hline 4. I feel enough support from the police whenever I need them. &, 935 \\
\hline 5. Regarding my work, we can easily agree with the police. &, 894 \\
\hline 6. The police always help me to overcome the difficulties I encounter during my work. &, 926 \\
\hline
\end{tabular}

Since the factor load value of the third item was found to be less than 30 , this item was removed from the scale and the EFA was repeated. In the test results, $\mathrm{KMO}=886$, Bartlett test (Chi-square $(10)=317,345 ; \mathrm{p}<0.001)$. Newly-formed factor loadings for scale items are presented in Table 6 (Demirci, 2019a).

Table 6. Items Factor Loaded of Draft Scale after the Item Removal

\begin{tabular}{|l|c|}
\hline \multicolumn{1}{|c|}{ Items } & Factor loaded \\
\hline 1. I can provide adequate communication with the police during my duty. &, 943 \\
\hline 2. In general, private security - police cooperation is at the top level. &, 845 \\
\hline 3. I feel enough support from the police whenever I need them. &, 936 \\
\hline 4. Regarding my work, we can easily agree with the police. &, 896 \\
\hline 5. The police always help me to overcome the difficulties I encounter during my work. &, 932 \\
\hline
\end{tabular}

As a result of the factor analysis, it was understood that the scale had a one-dimensional structure and explained $83 \%$ of the total variance.

The capability of an item in a scale to discriminate between the ones with high scores and those with the low scores is called item discrimination power. Item discrimination power is also accepted as the determination of the item validity. The internal consistency criterion $(\mathrm{t}-$ 
test) analysis can be used to determine the discriminative powers of the items in the Likert-type scales (Tezbaşaran, 1997). For this purpose, $27 \%$ of the scale with the highest score and the lowest score of $27 \%$ were grouped for comparison (Erkuş, $2003^{5}$ ).

Item means scores of 17 persons with the highest and lowest mean were divided into two groups. For each item, the t-Test was performed on the highest average score of $27 \%$ with the lowest average score of 27\%. t-Test results are presented in Table 7 (Demirci, 2019a).

Table 7. Draft Scale Items' T-Test Results

\begin{tabular}{|c|c|c|c|c|c|}
\hline Items & $N$ & $X$ & Ss & $T$ & $p$ \\
\hline \multirow{2}{*}{ Item 1} & 17 & 5,0000 & ,00000 & \multirow{2}{*}{18,000} & \multirow{2}{*}{,000 } \\
\hline & 17 & 2,3529 & ,60634 & & \\
\hline \multirow{2}{*}{ Item 2} & 17 & 4,5294 & ,51450 & \multirow{2}{*}{16,685} & \multirow{2}{*}{, 000} \\
\hline & 17 & 1,6471 & ,49259 & & \\
\hline \multirow{2}{*}{ Item 3} & 17 & 4,8235 & ,39295 & \multirow{2}{*}{15,162} & \multirow{2}{*}{,000 } \\
\hline & 17 & 1,8824 & ,69663 & & \\
\hline \multirow{2}{*}{ Item 4} & 17 & 4,8235 & ,39295 & \multirow{2}{*}{15,551} & \multirow{2}{*}{, 000} \\
\hline & 17 & 2,1176 & 60025, & & \\
\hline \multirow{2}{*}{ Item 5} & 17 & 4,6471 & 49259, & \multirow{2}{*}{13,887} & \multirow{2}{*}{,000 } \\
\hline & 17 & 2,0000 & ,61237 & & \\
\hline
\end{tabular}

As Table 7 was examined, it was revealed that significance values of all items $(\mathrm{p}<0.05)$ were significant in 95\% confidence interval according to t-Test results. According to these results, it was evaluated that all of the scale items have item discrimination power (Demirci, 2019a).

Obtaining by EFA, the structure of the scale was tested with CFA. The maximum likelihood technique was conducted to perform confirmatory factor analysis. The prerequisite for maximum likelihood technique is the normal distribution of data. Hence, the normality test was performed. The normality test results on the scale present in Table 8. According to Tabachnick and Fidell (2013), it was clarifying that the data was normally distributed that skewness and kurtosis values were between $-1,5$ and $+1,5$ for each item (Demirci, 2019a).

\footnotetext{
${ }^{5}$ The use of groups of $27 \%$ in the determination of pole groups was suggested by Kelley (1939), who found that $27 \%$ of the groups that made the variance maximum in the pole groups.
} 
As Table 8 is examined, it is seen that skewness and kurtosis of all items have sufficient values.

Table 8. Normality Test of The Draft Scale

\begin{tabular}{|c|c|c|}
\hline Items & Skewness & Kurtosis \\
\hline 1. I can provide adequate communication with the police during my duty. &,- 806 &,- 113 \\
\hline 2. In general, private security - police cooperation is at the top level. &,- 432 &,- 800 \\
\hline 3. I feel enough support from the police whenever I need them. &,- 633 &,- 509 \\
\hline 4. Regarding my work, we can easily agree with the police. &,- 582 &,- 533 \\
\hline 5. The police always help me to overcome the difficulties I encounter during my work. &,- 658 &,- 401 \\
\hline
\end{tabular}

When Table 9 is examined, the ratio of the chi-square statistic to the degrees of freedom of the scale CMIN / DF (X2 / df) was 2,248; (Normed Fit Index) NFI value was .966; (Incremental Fit Index) IFI value was .981; (Tucker-Lewis index) TLI value was .942; (Comparative Fit Index) CFI value was .981 and The RMSEA value was found to be .042. According to the results of this analysis, it was understood that the scale provided adequate compliance values. Hence, it is considered that the scale was capable to use for the main application (Demirci, 2019a).

Table 9. Draft Scales' Confirmatory Factor Analyses Results

\begin{tabular}{|c|c|c|c|c|c|c|}
\hline \multicolumn{1}{|c|}{$\boldsymbol{X}^{\mathbf{2}}$} & df & CMIN/DF & NFI & IFI & TLI & CFI \\
\hline $\mathbf{1 1 , 2 4 1}$ & 5 & 2,248 &, 966 &, 981 &, 942 &, 042 \\
\hline Acceptable compliance values & $<5$ & $>.90$ & $>.90$ & $>.90$ & $>.90$ \\
\hline Excellent compliance & $<3$ & $>.95$ & $>.95$ & $>.95$ & $>.95$ \\
\hline
\end{tabular}

As a result of the analysis, 702 data obtained from the actual application and the Cronbach's Alpha value of the scale was calculated as .925 (Demirci, 2019a). As a result of the normality test, it was reviewed that all skewness and kurtosis values were between $+1,5$ and 1,5. Hence, the data were evaluated as a normal distribution (Tabachnick and Fidell, 2013).

The questionnaire consists of totally 51 items, 8 of which are related to demographic information, 20 of which are related to Job Satisfaction Scale, 18 of which are related to 
Occupational Commitment Scale and 5 of which are related to Private Security Police Cooperation Level Scale.

\section{FINDINGS AND ANALYSES}

\subsection{Demographics of Participants}

$432(61.5 \%)$ of the participants were male and $270(38.5 \%)$ of them were female. $6(1 \%)$ of the participants were in the 18-23 age range, 84 (12\%) of them were between the 24-29 age range, $192(27.4 \%)$ of them were between the 30-35 age range and $420(59.8 \%)$ of them were 36 years and older. $486(69.2 \%)$ of the participants were married and 216 (30.8) were single. $90(12,8 \%)$ of the participants were primary school graduates, $348(49,6 \%)$ were graduated from high school, $204(29,1 \%)$ had an associate degree, $42(6 \%)$ had a bachelor's degree and $18(2,6)$ had a postgraduate degree. $528(75.2 \%)$ of the participants work at the public and 174 $(24.8 \%)$ of them work in the private sector. 564 (80.3\%) of the participants were employed at the units and $138(19.7 \%)$ were employed by the private security companies. $150(21.7 \%)$ of the participants earn between 1500-2000 TL, 342 (48.7\%) of them earn between 2001-2500 TL, $96(13.7 \%)$ of them earn between 2501-3000 TL and 114 (16.2\%) of them earn $3001 \mathrm{TL}$ and more. $12(1.7 \%)$ of the participants had a tenure of one year and less, $246(35 \%)$ had a tenure between 2-5 years, and $186(26.5 \%)$ had a tenure between 6-10 years, and $258(36 \%, 8)$ had a tenure of 11 years or more.

\subsection{Participants Level of Job Satisfaction, Occupational Commitment, and} Perception of Police Cooperation

Statistics on job satisfaction, occupational commitment, and perception of police cooperation are presented in Table 10. When Table 10 is examined, it is understood that the job satisfaction levels of the participants are 3,35 (moderate), the occupational commitment levels are 3,12 (moderate) and the perception of police cooperation is 3,62 (high).

Table 10. Participants Level of Job Satisfaction, Occupational Commitment, and Perception of Police Cooperation

\begin{tabular}{|l|c|c|c|}
\hline & N & Mean & Standard deviation \\
\hline Job satisfaction & 702 & 3,3453 &, 72618 \\
\hline Occupational commitment & 702 & 3,1239 &, 48556 \\
\hline Police cooperation perception & 702 & 3,6154 &, 92262 \\
\hline
\end{tabular}




\subsection{The Effect of Police Cooperation Perception on the Relationship between Job}

\section{Satisfaction and Occupational Commitment}

Multiple regression analysis was performed to determine the effect of police cooperation perception on the relationship between job satisfaction and occupational commitment. Within the context of the steps stated by Baron and Kenny (1986), firstly a regression analysis was carried out between job satisfaction and police cooperation perception, then another regression analysis was carried out between job satisfaction and occupational commitment, and finally, by adding police cooperation perception to the second stage of the model, the regression analysis was repeated. The results of the regression analysis for all three models are presented in Table 11.

Table 11. Regression Analyses on the Relationship among Job Satisfaction, Occupational Commitment, and Perception of Police Cooperation

\begin{tabular}{|c|c|c|c|c|c|c|c|c|c|}
\hline \multicolumn{2}{|c|}{ Steps } & $\boldsymbol{\beta}$ & $\mathbf{R}$ & $\mathbf{R}^{2}$ & $\mathbf{t}$ & Adjusted $\mathbf{R}^{2}$ & $\mathbf{R}^{2}$ & Sig. of $F$ & $F$ for \\
\hline \multicolumn{2}{|l|}{ 1. Step } & & & & & & & & \\
\hline \multicolumn{2}{|c|}{$\begin{array}{l}\text { Job satisfaction-Police cooperation } \\
\text { perception }\end{array}$} & .460 & .460 & .212 & 13.722 & . 211 & .212 & .000 & 188.287 \\
\hline \multicolumn{2}{|l|}{ 2. Step } & & & & & & & & \\
\hline \multicolumn{2}{|c|}{$\begin{array}{l}\text { Job satisfaction-Occupational } \\
\text { commitment }\end{array}$} & .426 & .426 & .182 & 12.472 & .181 & .182 & .000 & 155.545 \\
\hline \multirow{2}{*}{$\begin{array}{l}\text { 3. Step } \\
\text { Job } \\
\text { satisfaction+Police } \\
\text { cooperation } \\
\text { perception- } \\
\text { Occupational } \\
\text { commitment }\end{array}$} & $\begin{array}{l}\text { Job } \\
\text { satisfaction }\end{array}$ & .214 & & & 6.220 & & & & \\
\hline & $\begin{array}{l}\text { Police } \\
\text { cooperation } \\
\text { perception }\end{array}$ & .462 & .592 & .350 & 13.451 & . 348 & .350 & .000 & 188.232 \\
\hline
\end{tabular}

$\mathrm{p}<.005$

When Table 11 is examined, it was found that there was a significant relationship between job satisfaction and police cooperation perception, and the regression model was found statistically significant $(\beta=0.460$ and $\mathrm{p}<.005)$. The first condition was met. Secondly, it was found that there was a significant relationship between job satisfaction and occupational commitment and the regression model was found statistically significant $(\beta=0.426$ and $p$ $<.005)$. The second condition was met and also the $\mathrm{H}_{1}$ hypothesis is accepted. Finally, the 
regression model, which was formed when the police cooperation perception was included in the regression model in the second step, was still statistically significant $(\beta=0,214$ and $\mathrm{p}<.005)$ but the beta value decreased from .460 to .214 . According to these results, it can be stated that the perception of police cooperation may have a partial mediating effect in the relationship between job satisfaction and occupational commitment.

The Sobel Test was performed to determine the exact mediating effect. The Sobel Test result is presented in Table 12. It is seen that the $\mathrm{Z}$ value obtained as a result of the Sobel Test is as $(10.9470$ and $\mathrm{p}<.005)$. According to these results, it was determined that the decrease in beta value was significant and that the perception of police cooperation had a partial mediating effect in the relationship between job satisfaction and occupational commitment. So, the $\mathrm{H}_{2}$ hypothesis is accepted.

Table 12. The Results of the Sobel Test

\begin{tabular}{|r|c|c|c|c|}
\hline \multicolumn{2}{|c|}{ Values } & Test statistics & Standard deviation & \\
\hline $\boldsymbol{a}$ & .585 & & \\
\hline $\boldsymbol{b}$ & .295 & 10.9470 & .01576 & .000 \\
\hline $\boldsymbol{s}_{\boldsymbol{a}}$ & .043 & & & \\
\hline $\boldsymbol{s}_{b}$ & .016 & & \\
\hline
\end{tabular}

\section{CONCLUSION AND DISCUSSION}

According to the results of the studies conducted by Barac et al. (2018), Satoh et al. (2017), Kuo (2014), Moradi et al. (2013), Wang et al. (2011) and Lu et al. (2007), it was found out that there was a relationship between job satisfaction and occupational commitment. Research results confirm this hypothesis. In the study, it was found that there was a .426 (moderate) correlation between job satisfaction and occupational commitment, and job satisfaction explained $18 \%$ of the occupational commitment. This result is similar with the research result found out by Barac et al. (2018). However, although Moradi et al. (2013) found a .324 (weak) correlation, Wang et al. (2011) found a .714 (high) correlation between the two variable.

Since the relationship level between job satisfaction and occupational commitment differ according to the results of studies conducted by Barac et al., (2018); Moradi et al., (2013); and Wang et al., (2011), the perception on the private security and the police cooperation, which 
is known to have an effect on both job satisfaction (Demirci, 2019a) and occupational commitment (Demirci, 2019b), is considered to have a mediating effect on the relationship between these variables. Research results also confirm this hypothesis. The private security officers' police cooperation perception has a partial mediating effect on the relationship between job satisfaction and occupational commitment. Research results indicate that there may be other factors that affect the relationship between job satisfaction and occupational commitment. For this reason, it is considered that there is a need for researches to discover the factors that have a mediating effect in order to reveal the relationship between job satisfaction and occupational commitment.

The results of the research show that the perception of police cooperation is important for private security officers. The relationship and cooperation to be developed between the private security and the police will have a direct impact on the private security officers' job satisfaction and occupational commitment, and it will have an indirect effect on their occupational commitment along with job satisfaction. Therefore, the relationship and cooperation projects between the private security and the police can help to prevent the loss of the human resources in the industry by increasing the occupational commitment of private security officers as well as the benefits of achieving the general objectives of the projects. On the other hand, private security officers can be provided with many useful job attitudes such organizational commitment, motivation, organizational citizenship behavior by keeping their occupational commitment levels high.

In order to increase the relationship between police and private security, performing some practices can be beneficial. For example, crime prevention policies in which police and private security work together, can be developed. Moreover, training programs can be conducted which police can transfer its crime prevention experience to the private security officers. In this way, private security officers will understand the essence and professional image of their job and be satisfied by job itself, and they will have job satisfaction, thus increasing their professional commitment levels. So, both efficient public safety and an increase in the occupational commitment of private security officers can be enhanced.

Due to the specific nature of the occupation, the factors affecting the occupational commitment of the private security officers vary. Therefore, it is necessary to carry out studies to determine the factors affecting the occupational commitment of private security officers. Meanwhile, there are also many professional factors that affect occupational commitment. How professional and respected the job is important for those who perform the occupation. 
Therefore, it may have an effect on private security officers' occupational commitment. In this context, revealing the professionality level of the private security occupation, it may be useful to put forth the necessities for it to be much more professional.

There are some limitations to this research. First of all, this research was designed and conducted as a relational model. Conducting experimental research can be more reliable and the results of that research can be much more generalizable. This research was conducted in Bursa province in October 2018. It is known that both job satisfaction and occupational commitment are affected by many factors such as age, gender, pay, education, etc. Therefore, the results of the research which will be conducted in different provinces and during different time periods might show differences. 


\section{REFERENCES}

Ahsan, N., Abdullah, Z., Yong, D. and D.Yong, G. (2008). A Study of Job Stress on Job Satisfaction among University Staff in Malaysia: Empirical Study.European Journal of Social Sciences, 8 (1), 121-131.

Aledeinat M., Harith, M. ve Shahar, M. (2017). The Effect of Job Involvement and Professional Commitment on Organizational Citizenship Behavior: (A Conceptual Framework). International Journal of Management Sciences and Business Research, 6 (9), 28-34.

Aranya, N. and Ferris, K.R. (1984). A Reexamination of Accountants' Organizational-Professional Conflict. The Accounting Review, 59 (1), 1-15.

Armstrong, M. (2006). A Handbook of Human Resource Management Practice, Tenth Edition, Kogan Page Publishing, London.

Aslan, Ş. (2008). Örgütsel Vatandaşlık Davranışı ile Örgütsel Bağlılık ve Mesleğe Bağlılık Arasındaki İlişkilerin Araştırılması. Yönetim ve Ekonomi, Celal Bayar Üniversitesi İktisadi ve İdari Bilimler Fakültesi Dergisi, 15(2), 163-178.

Awalina, P., Saraswati, E. and Roekhudin (2015). The Influence of Professional Commitment and Job Satisfaction Towards Turnover Intention. IOSR Journal of Business and Management, 17 (6), 21-28.

Aydıntan, B. ve Koç, H. (2016). The Relationship between Job Satisfaction and Life Satisfaction: An Empirical Study on Teachers. International Journal of Business And Social Science, 7 (10), 72-80.

Bakan, I., Büyükbeşe, T., Ersahan, B. and Sezer, B. (2014). Effects of Job Satisfaction on Job Performance and Occupational Commitment. International Journal of Management \& Information Technology, 9 (1), 14721480 .

Barac, I., Prlic, N., Pluzaric, J., Farcic, N. and Kovacevic, S. (2018). The Mediating Role of Nurses' Professional Commitment in The Relationship between Core Self-Evaluation and Job Satisfaction. International Journal of Occupational Medicine and Environmental Health, 31 (5), 649-658.

Baron, R.M. and Kenny, D.A. (1986). The Moderator Variable Distinction in Social Psychological Research: Conceptual, Strategic, and Statistical Considerations. Journal of Personality and Social Psychology, 51 (6), 1173-1182.

Baysal A.C. and Paksoy M. (1999). Mesleğe ve Örgüte Bağlılığın Çok Yönlü Incelemesinde Meyer-Allen Modeli. İ.Ü. İşletme Fakültesi Dergisi, 28, 1-15

Benligiray, S. and Sönmez, H. (2011). Hemşirelerin Mesleki Bağlılıkları ile Diğer Bağlılık Formları Arasındaki İlişki: Örgüte Bağlılık, İşe Bağlılık ve Aileye Bağlılık. Hacettepe Üniversitesi Sağlık Bilimleri Yüksekokulu Hemşirelik Dergisi, 18(1), 28-40.

Benligiray, S. and Sönmez, H. (2013). The Analysis of Demographic and Work Life Variables Which Affect The Occupational Commitment of Nurses. Journal of Management Development, 32(4), 419-434.

Blau, G. (1985). The Measurement and Prediction of Career Commitment. Journal of Occupational Psychology, $58,277-288$.

Blau, G. (2000). Job, Organizational, and Professional Context Antecedents As Predictors of Intent for Interrole Work Transitions. Journal of Vocational Behavior, 56, 330345.

Blau, G. (2001). Testing the Discriminant Validity of Occupational Entrenchment. Journal of Occupational and Organizational Psychology, 74, 85-93.

Blau, G. (2003). Testing for A Four-Dimensional Structure of Occupational Commitment. Journal of Occupational and Organizational Psychology, 76, 469-488. 
Böckerman, P. and Ilmakunnas, P. (2012). The Job Satisfaction-Productivity Nexus: A Study Using Matched Survey and Registered Data. Industrial \& Labor Relations Revies, 65 (2), 244-262.

Buitendach, J. H. and Rothmann, S. (2009). The Validation of The Minnesota Job Satisfaction Questionnaire in Selected Organizations in South Africa. SA Journal of Human Resource Management, 7 (1). 1-8.

Cetin, M.O. (2006). The Relationship Between Job Satisfaction, Occupational and Organizational Commitment of Academics. Journal of American Academy of Business, 8 (1), 78-88.

Chinwokwu, E.C. (2018). An Assessment of The Relationship between Private Security Companies and The Police in Crime Prevention in Lagos Metropolis, Nigeria. International Journal of Police Science \& Management, 20 (1), 80-93.

CoESS (2010). Critical Infrastructure Security and Protection: The Public-Private Opportunity. Wemmel, Belgium.

Cohen, A. (2007). Dynamics between Occupational and Organizational Commitment in The Context of Flexible Labor Markets: A Review of The Literature and Suggestions for A Future Research Agenda. Inst. Technik Und Bildung.

Crime Research Centre (2008). Evaluation of The Eyes on The Street Program. Perth: Crime Research Centre, University of Western Australia.

Crossman, A. and Abou-Zaki, B. (2003). Job Satisfaction and Employee Performance of Lebanese Banking Staff. Journal of Managerial Psychology, 18(4), 368-376.

Culbertson, S.S., Henning, J.B. and Payne, S.C. (2013). Performance Appraisal Satisfaction The Role of Feedback and Goal Orientation. Journal of Personnel Psychology, 12 (4), 189-195.

Cunningham, P. H., Tang, T. L. P., Frauman, E., Ivy, M. I. and Perry, T. L. (2012). Leisure Ethic, Money Ethic, and Occupational Commitment among Recreation and Park Professionals: Does Gender Make A Difference? Public Personnel Management, 41 (3), 421-448.

Cunningham, W. C. and Taylor, T.H. (1985). The Hallcrest Report: Private Security and Police in America. Portland, Ore.: Chancellor Press.

Demirci, (2019a). Özel Güvenlik Polis İşbirliğinin Özel Güvenlik Görevlilerinin İş Doyumları Üzerine Etkisi. İşletme Araştırmaları Dergisi, 11 (1), 490-503.

Demirci, U. (2019b). The Effect of Private Security Police Cooperation Perception on Private Security Officers' Professional Commitment Level. The International Journal of Business \& Management. 7 (4), 71-81.

Ellickson. M.C. and Logsdon, K. (2002). Determinants of Job Satisfaction of Municipal Government Employees [Electronic Version]. Public Personnel Management, 31(3), 343-358.

Erkuş, A. (2003). Psikometri Üzerine Yazılar. Ankara: Türk Psikologlar Derneği Yayınları.

Fırat, M. Z. (2015). Tükenmişlik ve Örgütsel Bağlılığın Mesleki Bağlılık Üzerindeki Etkileri: Banka Çalışanları Üzerinde Bir Araştırma. (Unpublished Doctorate Thesis). İstanbul: Haliç Üniversitesi.

Foote, D.A., Li, T. and Tang, T.L. (2008). Job Satisfaction and Organizational Citizenship Behavior (OCB) Does Team Commitment Make a Difference in Self-Directed Teams?. Management Decision, 46 (6), 933-947.

Furnham, A., Eracleous, A., and Chamorro-Premuzic, T. (2009). Personality, Motivation and Job Satisfaction: Hertzberg Meets The Big Five. Journal of Managerial Psychology, 24 (8), 765-779.

Ghiselli, R.F., Lalopa, J.M. and BAI, B. (2001). Job Satisfaction, Life Satisfaction and Turnover Intent: Among Food Service Managers. Cornell Hotel and Restaurant Administration Quarterly, 42 (2), 28-37. 
Goswami, S., Mathew, M. and Chadha, N.K. (2007). Differences in Occupational Commitment amongst Scientists in Indian Defence, Academic, and Commercial ROD Organizations. VIKALPA, 32 (4), 13-27.

Griffiths, C.T. and Montgomery, R. (2015). The Use of Private Security Services for Policing. Research Report: 2015-R041. https://www.publicsafety.gc.ca/cnt/rsrcs/pblctns/archive-2015-r041/2015-r041-en.pdf Date of access: 14.05.2019.

Gülcü, M. (2002). Özel Güvenliğin Felsefesi (I). Polis Dergisi, 36, 58-70.

Güleryüz, G., Güney, S., Aydın, E. M. and AS, Ö. (2008). The Mediating Effect of Job Satisfaction between Emotional Intelligence and Organizational Commitment of Nurses: A Questionnaire Survey. International Journal of Nursing Studies. 45, 1625-1635.

Gürbüz, A. (2007). An Assessment on The Effect of Education Level on The Job Satisfaction from The Tourism Sector Point of View. Doğuş Üniversitesi Dergisi, 8 (1), 36-46.

Hançer, M. and George, R. T. (2003). Job Satisfaction of Restaurant Employees: An Emprical Investigation Using The Minnesota Satisfaction Questionnaire. Journal of Hospitality\&Tourism Research, 27 (1), 85-100.

Hoppock, R. (1935). Job Satisfaction, Harper and Brothers, New York.

Iaffaldano, M. T., And Muchinsky, P.M. (1985). Job Satisfaction and Job Performance: A Meta-Analysis. Psychological Bulletin, 97(2): 251-73.

Jalagat, R., Dalluay, V., Al-Zadjali, A.K. and Al-Abdullah, A. (2017). The Impacts of Job Satisfaction on Employee Turnover: A Case Study of Oman Air in Sultanate Of Oman. European Academic Research, 5, 331-374.

Jauch, L.R., Glueck, W.F. and Osborn, R.N. (1978). Organizational Loyalty, Professional Commitment, and Academic Research Productivity. The Academy of Management Journal, 21 (1), 84-92.

Kaldenberg, D. O., Becker, B. W. and Zvonkovic, A. (1995). Work and Commitment among Young Professionals: A Study of Male and Female Dentists. Human Relations, 48 (11), 1355-1377.

Karataş, S. and Güleş, H. (2010). İlköğretim Okulu Öğretmenlerinin İş Tatmini ile Örgütsel Bağlılığı Arasındaki İlişki. Uşak Üniversitesi Sosyal Bilimler Dergisi. 3 (2), 74-89.

Khan, A.H., Nawaz, M.M, Aleem, M. and Hamed, W. (2011) Impact of Job Satisfaction on Empleyee Performance: An Empirical Study of Autonomous Medical Institutions of Pakistan. African Journal of Business Management, 6-7, 2697-2705.

Kuo, S. (2014). Occupational Stress, Job Satisfaction, and Affective Commitment to Policing among Taiwanese Police Officers. Police Quarterly, 18 (1), 27-54.

Lanchman, R. and Aranya, N. (1986). Evaluation of Alternative Models of Commitment and Job Attitudes of Professionals. Journal of Occupational Behaviour, 7, 227-243.

Lauermann, F., Karabenick, S., Carpenter, R. and Kuusinen, C. (2017). Teacher Motivation and Professional Commitment in The United States The Role of Motivations for Teaching, Teacher Self-Efficacy and Sense of Professional Responsibility. (In H. M. G. Watt, P. W. Richardson, \& K. Smith (Eds.), Current Perspectives in Social and Behavioral Sciences. Global Perspectives on Teacher Motivation (322-348). New York, NY, US: Cambridge University Press.

Lee K., Carswell J.J and Allen N.J.(2000). A Meta-Analytic Review of Occupational Commitment: Relation With Person and Work-Related Variables, Journal of Applied Psychology, 85, 799-811.

Lee, K., Carswell, J. J. and Allen, N. J. (2000). A Meta-Analytic Review of Occupational Commitment: Relations With Person and Work Related Variables. Journal of Applied Psychology, 85, 799-811. 
Lim, V. K. G., Teo, T. S. H. and See, S. K. B. (2000). Perceived Job Image among Police Officers in Singapore: Factorial Dimensions and Differential Effects. Journal of Social Psychology, 140, 740-750.

Locke, E. A. (1995). Commentary: The Micro-Analysis of Job Satisfaction: Comments on Taber and Alliger [Electronic Version], Journal of Organizational Behavior, 16(2), 123-126.

Louis,K.S. (1998). Effects of Teacher Quality of Work Life in Secondary Schools in Relation to Commitment and Sense of Efficacy. School Effectiveness and School Improvement, 9 (1), 1-2.

Lu, K., Chang, L. and Wu, H. (2007). Relationships between Professional Commitment, Job Satisfaction, and Work Stress in Public Health Nurses in Taiwan. Journal of Professional Nursing, 23 (2), 110-116.

Lu, K., Lin, P., Wu, C., Hsieh, Y. and Chang, Y. (2002). The Relationships among Turnover Intentions, Professional Commitment, and Job Satisfaction of Hospital Nurses. Journal of Professional Nursing, 18(4), 214-219.

Mccann, J., Graves, D. and Cox, L. (2014). Servant Leadership, Employee Satisfaction, and Organizational Performance in Rural Community Hospitals. International Journal of Business and Management, 9 (10), 2838.

McShane, S. (1984). Job Satisfaction and Absenteeism: A Meta-Analytic Re-Examination. Canadian Journal of Administrative Science, 1 (1), 61-77.

Meyer, J. P. and Espinoza, J. A. (2016). Occupational Commitment. In J. P. Meyer (Ed.). Handbook of Employee Commitment (Ss.135-149). Cheltenham, UK: Edward Elgar Publishing.

Meyer, J.P, Allen, N.J. and Smith, C.A. (1993). Commitment to Organizations and Occupations: Extension and Test of A Three-Component Conceptualization. Journal of Applied Psychology, 78, 538-551.

Moradi, M., Khatooni, M., Zeighami, R., and Sheikhi, M. (2013). Relationship between Professional Commitment and Job Satisfaction in Qazvin's Pubic Educational Hospital Nurses. Medical Ethics Journal, 7 (24), 55-78.

Morley, H. and Fong, R. (1995). Can We All Get Along? A Study of Why Strained Relations Continue to Exist Between Sworn Law Enforcement and Private Security. Security Journal. 6, 85-92.

Morrow, P. C. (1983). Concept Redundancy in Organizational Research: The Case of Work Commitment. Academy of Management Review, 8, 486-500.

Nadinloyi, K.B., Sadeghi, H. and Hajloo, N. (2013). Relationship Between Job Satisfaction and Employee Mental Health. Procedia-Social and Behavioral Sciences, 84, 293-297.

Nalla, M. K. and Hwang, E. (2006). Relations Between Police and Private Security Officers in South Korea. Policing: An International Journal of Police Strategies \& Management, 29 (3), 482-497.

Nalla, M.K. and Hummer, D. (1999). Relations between Police Officers and Security Professionals: A Study of Perceptions, Security Journal, 12, 31-40.

Nelson, D. L. and Quick, J.C. (1995) Organizational Behavior: Foundations, Realities, and Challenges. Alternate Edition. New York: West Company.

Nguyen, A.N., Taylor, J. and Bradley, S. (2003). Relative Pay and Job Satisfaction: Some New Evidence. Working Paper 045, Department of Economics, Lancaster University Management School. Https://Mpra.Ub.UniMuenchen.De/1382/1/MPRA_Paper_1382.Pdf

Nwankwo, B., Agu, S., Sydney-Abor, N and Chikwendu, C. (2016). The Relationship Between Job Satisfaction and Job Involvement Among Secondary School Teachers. International Journal of Case Studies, 3 (3), 2127.

Ocpara, J.O., Squillace, M. and Erondu, E.A. (2005). Gender Differences and Job Satisfaction: A Study of University Teachers in The United States. Women in Management Review, 20 (3), 177-190. 
Oran, N.B. (1989). A Study on Job Satisfaction of A Group of Academical Staff in Marmara University. (Unpublished Master Thesis). İstanbul: Marmara Üniversitesi Sosyal Bilimler Enstitüsü.

Özdemir, F. (2006). Örgütsel İklimin İş Tatmin Düzeyine Etkisi: Tekstil Sektöründe Bir Araştırma. (Unpublished Doctorate Thesis). Adana: Çukurova Üniversitesi Sosyal Bilimler Enstitüsü,

Özdevecioğlu, M. and Aktaş, A. (2007). Kariyer Bağlılığı, Mesleki Bağlılık ve Örgütsel Bağlılığın Yaşam Tatmini Üzerindeki Etkisi: İş-Aile Çatışmasının Rolü. Erciyes Üniversitesi İktisadi ve İdari Bilimler Fakültesi Dergisi, (28), 1-20.

Özer, G. and Uyar, M. (2010), Muhasebecilerin Etik Oryantasyonlarının Mesleki Bağl1lığa Etkisi Üzerine Bir Inceleme. Muhasebe ve Finansman Dergisi, 48, 89-100.

Özmen, Ö.T, Özer, P.S. and Saatçioğlu, Ö.Y. (2005). Akademisyenlerde Örgütsel ve Mesleki Bağlılığın İncelenmesine İlişkin Bir Örnek Araştırma. İşletme Fakültesi Dergisi, 6(2), 1-14.

Parasuraman, S. and Nachman, S. (1987). Correlates of Organizational and Professional Commitment. Group \& Organization Studies, 12(3), 287-303.

Parvin, M.M. and Kabir, M.M.N. (2011). Factors Affecting Employee Job Satisfaction of Pharmaceutical Sector. Australian Journal of Business and Management Research, 1 (9), 113-123.

Raiziene S. and Endriulaitiene A. (2007). The Relations among Empathy, Occupational Commitment, and Emotional Exhaustion of Nurses. Medicina (Kaunas). 43 (5), 425-31.

Saner, T. and Eyüpoğlu, Ş.Z. (2012). The Age and Job Satisfaction Relationship in Higher Education. Social and Behavioral Sciences, 55, 1020-1026.

Sarre, R. (2011). The Future of Police Cooperation Police and Private Sector Partnerships: Trends and Issues. Proceedings of The 2010 Nordic Police Research Conference, 183-195.

Satoh, M., Watanabe, I., and Asakura, K. (2017). Factors Related to Affective Occupational Commitment Among Japanese Nurses. Open Journal of Nursing, 7, 449-462.

Schmidt, J. A., and Lee, K. (2008). Voluntary Retirement and Organizational Turnover Intentions: The Differential Associations With Work and Non-Work Commitment Constructs. Journal Of Business and Psychology', 22, 297-309.

Sevimli, F. and İşcan, Ö.F. (2005). Bireysel ve İş Ortamına Ait Etkenler Açısından İş Doyumu. Ege Üniversitesi, İ.İB.F. Akademik Bakış Dergisi, 5 (1-2), 55-64.

Shamina, H. (2014). Impact of Job Satisfaction on Professional Commitment in Higher Education. GALAXY International Interdisciplinary Research Journal. 2 (2), 1-11.

Snape, E., Lo, C. W. H. and Redman, T. (2008). The Three-Component Model of Occupational Commitment A Comparative Study of Chinese and British Accountants. Journal of Cross-Cultural Psychology, 39, 765-781.

Sobel, M. E. (1982). Asymptotic Confidence Intervals for Indirect Effects in Structural Equation Models. Sociological Methodology, 13, 290-312. doi:10.2307/270723..

Sobel, M. E. (1986). Some New Results on Indirect Effects and Their Standard Errors in Covariance Structure. Sociological Methodology, 16, 159-186. doi:10.2307/270922.

Sotlar, A. and Mesko, G. (2009). The Relationship Between The Public and Private Security Sectors in SloveniaFrom Coexistence Towards Partnership?. VARSTVOSLOVJE, 11 (2), 269-285.

Şimşek, M.Ş., Akgemci, T., and Çelik, A., (2007) Davranış Bilimlerine Giriş ve Örgütlerde Davranış, Ankara.

Tabachnick, B.G. and Fidell, L.S. (2013). Using Multivariate Statistics (sixth ed.). Pearson, Boston. 
Tak, B., and Çiftçioğlu, B. A. (2008). Mesleki Bağlılık ile Çalışanların Örgütte Kalma Niyeti Arasındaki İlişkiyi Incelemeye Yönelik Görgül Bir Çalışma. Ankara Üniversitesi Siyasal Bilgiler Fakültesi Dergisi, 63 (4), 155 178.

Tang, T.L.P., Cunningham, P.H., Frauman, E., Ivy, M.I. and Perry, T.L. (2012). Attitudes and Occupational Commitment among Public Personnel: Differences between Baby Boomers and Gen-Xers. Public Personnel Management, 41 (2), 327-360.

Tezbaşaran, A. A. (1997). Likert Tipi Ölçek Geliştirme Kılavuzu. Ankara: Türk Psikologlar Derneği.

Van den Berg, E. (1995). Crime Prevention on Industrial Sites: Security Through Public-Private Partnerships. Security Journal, 6(1), 27-35.

Vieira, J.A.C. (2005). Skill Mismatches and Job Satisfaction. Economic Letters, 89, 39-47.

Wakefield, A. 2003. Selling Security: The Private Policing of Public Space, Portland: Willan.

Wang, L., Tao, H., Ellenbecker, C.H. and Liu, X. (2011). Job Satisfaction, Occupational Commitment and Intent to Stay Among Chinese Nurses: A Cross-Sectional Questionnaire Survey. Journal of Advance Nursing, 68 (3), 539-549.

Weiss, D. J., Dawis, R. V. England, G. W. and Lofquist, L. H. (1967), Manual for the Minnesota Satisfaction Questionnaire. Vol. 22, Minnesota Studies in Vocational Rehabilitation, Minneapolis: University of Minnesota, Industrial Relations Center.

Woods, S.A., Poole, R. and Zibarras, L. (2012). Employee Absence and Organizational Commitment Moderation Effects of Age. Journal of Personnel Psychology, 11 (4), 1-23.

Yazıcıŏ̆lu, İ. (2010). Örgütlerde İş Tatmini ve İşgören Performansı İlişkisi: Türkiye ve Kazakistan Karşılaştırması. Bilig, 55, 243-264.

Yetgin, D. (2017). Turist Rehberlerinin Tükenmişlik ve Ekonomik Kaygı Düzeylerinin Mesleki Bağlılık Düzeyleri Üzerindeki Etkisi. (Unpublished Doctorate Thesis). Eskişehir: Anadolu Üniversitesi Sosyal Bilimler Enstitüsü.

Yılmaz, T. (2014). Çalışanların İş Tatmini ve Motivasyon Düzeyleri Arasındaki İlişkinin İncelenmesi: Kamu Çalışanları Üzerinde Bir Araştırma. (Unpublished Master Thesis). Ankara: Gazi Üniversitesi Eğitim Bilimleri Enstitüsü. 